\section{Deep Petroleum Wells}

Mr. W. A. SAwdon contributes an interesting article to a recent issue of the Oil Weekly concerning the deepest oil wells yet drilled. The record which he gives proves conclusively the high state of efficiency to which petroleum engineering has attained in the last few years, and it would seem that, both from a technical and an economic point of view, the limit to the depth probed for oil has yet to be defined. The appearance of this article is timely owing to the fact that the deepest well drilled in the United States has just been completed in Califormia, where a depth of 10,296 ft. has been reached. A feature of this well is that it was drilled with comparatively light equipment, contrary to the usual custom of involving extra heavy plant in order to achieve the great depths desired. This Californian well is not the deepest in the world, the record being held by a well drilled to $10,585 \mathrm{ft}$. in the State of Vera Cruz, Mexico. The first 10,000 ft. well to be drilled was, however, in California ; this attained a depth of 10,054 ft. but, like the Mexican well, no production was obtained. Probably the greatest producing well is that which was completed in July last in California at a depth of 9,710 ft., from which an initial production of 5,050 barrels of oil a day, accompanied by $5,000,000 \mathrm{cub}$. ft. of gas, was obtained. All these wells were rotary drilled.

Two other interesting oil wells may be added to the list; one drilled by the percussion system (cable tool) in West Virginia to 9,104 ft., from which no production was obtained, the other, a Texas well, also drilled by the cable tool system to a depth of $8,900 \mathrm{ft}$. In the latter case a Diesel engine was employed as motive power instead of the more customary steam engine or electric motor as in the case of the other wells mentioned. Apart from technical development, in future the utility of the deep well will be governed entirely by economic circumstances, since any attempt to raise oil from a depth of two miles or more in the earth's crust must necessarily involve considerably greater expenditure in plant, equipment and running costs than has been the case in the past for shallower wells. There is little question that, assuming it is economic. ally practicable, the petroleum engineering industry is capable of evolving both plant and operative system for attaining still greater depths, especially in cases where deeper-lying pay sands have to be tapped for the oil they contain. It is perhaps not difficult to visualise the day when over-production of oil will be a thing of the past and when reliance for the major part of the world's supply of crude petroleum will have to be placed on these very deep wells and on the revolutionised drilling technique which they imply.

\section{Modern Methods in the Inland Telegraph Service}

During the last two years, very rapid development has taken place in the inland telegraph service in Great Britain. Previously, a very exhaustive study had been made to find out the best methods of making the service more attractive to the public, more efficient as a means of communication, and less costly as regards the loss of State revenue. Instruments and machinery now to the service have been introduced. Teleprinters, typewriters, rectifiers, converters, thermionic valves and voice frequency signalling are the main features of the reorganised system. In a paper read to the Institution of Electrical Engineers on November 17, Mr. R. P. Smith described the new equipment in detail. A telegraph exchange service, 'the telex', has been made available to telephone subscribers, the necessary apparatus being installed on rental terms. The renters are able to receive and transmit printed communications in addition to the usual telephone facilities. They can also transmit messages to the Post Office, creating a new class of traffic designated 'Printergrams'-a word which we think not very happily chosen. We have now telegrams, phonograms and printergrams. At the present time, the supply of underground conductors is more than sufficient for the requirements of the public services. The vacant channels of communication are offered to the public, on rental terms, for the purpose of private wire circuits. The ascertained results of the reorganisation, which is still far from complete, show that the stability and accuracy of the service has been greatly increased. In addition, the latest figures show an improvement in the financial position. The changes also have increased the comfort and convenience of the army of vorkers who staff the telegraph instrument rooms.

\section{Aerial Spotting of Fish Shoals}

Since 1919, when the American Bureau of Fisheries first observed that fish shoals which could not be seen from the bridge of a ship were easily discernible from an aeroplane flying directly overhead, numerous attempts have been made to utilise aircraft for spotting shoals of fish. In Great Britain both the Ministry of Agriculture and Fisheries and the Scottish Fishery Board have made endeavours to locate herring shoals from the air but in both cases the experiments yielded no fruitful results. In the recently published report of the Danish Biological Station for 1932 interesting records of similar efforts to spot herring in Danish waters are given. Dr. $H$. Blegvad, director of the station, was in charge of the investigations and himself acted as observer. An important feature of the Danish experiments was that the Danish Broadcasting Corporation agreed to broadcast at once any information submitted to it from the exploring aeroplane. Unfortunately, only very few exceedingly small herring shoals were observed throughout the entire course of the investigations, which extended over forty flying hours. Their positions were immediately broadcast but the investigators were unable afterwards to obtain any information as to whether or not the broadcasts proved useful to the fishermen. Probably this entire lack of evidence is a very good indication of lack of positive results. The Danish investigators, therefore, like their British colleagues, have come to the

$$
\text { No. 3291, VoL. 130] }
$$


conclusion that, although in favourable conditions fish shoals in their waters may be spotted from the air, this method of loeating fish is much too costly and uncertain to be of any practical value to the national fisheries.

\section{The Future of Indian Agriculture}

IN a survey and a forecast of the next twenty years in India (Journal of the Royal Central Asian Society, vol. 19, July 1932), Lieut.-Col. Sir Arnold Wilson makes a strong plea for the introduction of scientific method into public affairs. $\mathrm{He}$ predicts that in twenty years time the population of Asia will have increased by at least 20 per cent, and that in India alone the numbers may have grown to 427 millions. These figures mean that the great problem of the future will be that of food supply. Over the whole of Asia the predominant occupation is agriculture, while in India at least the cultivable area increases very slowly and seems to have reached the limit except for the redemption of barren areas by irrigation. Figures tend to show that in India the food yield has not kept pace with the growth of population, but that the gap has been partly filled by a decrease in the export of grain. Sir Arnold Wilson foresees the dwindling of this export trade and the growth of an import trade in wheat. To balance this, India will have to develop an export of other primary products, but the tendency will be to utilise these at home. An import of fertilisers will, however, be essential, for on the extended use of these in agriculture lies one of the few hopes for the avoidance of famine in the future and the maintenance of the present standard of living, low as it is.

\section{Fenland Exploration in East Anglia}

A communication from Mr. Miles C. Burkitt, which appears in Man for November, announces the inauguration of a committee for the exploration of the fens of East Anglia in connexion with the Cambridge Antiquarian Society and the Prehistoric Society of East Anglia. Recent archæological work in the area, notably a study of the prehistoric waterways by Major Fowler of Ely and of an early metal age site below peat by $\mathrm{Mr}$. Grahame Clark, has served to demonstrate the importance of a region which can afford an unbroken sequence of deposits from quaternary to recent times. It is evident, however, that archæological investigation does not cover a sufficiently wide field for the complete study of the area, but needs supplementing by such studies, for example, as palæobotany and geology. It has, therefore, been decided, as already stated, to appoint a committee of experts to undertake systematic study in the various branches of scientific investigation between which co-operation is essential to a scheme of exploration. The Master of Downing, Prof. A. C. Seward, has consented to act as president and Major Fowler as vice-president of the Committee. Mr. Grahame Clark, Peterhouse, Cambridge, to whom communications relating to the work of the committee should be addressed, will act as secretary.

No. 3291, Vor. 130]

\section{Rediscovery of an 'Extinct' Bird}

RE-APPEARANCES of creatures regarded as extinet are occasionally reported but seldom proved. There can be no reasonable doubt, however, in the case of the black-capped petrel or 'diablotin' of Dominica, Pterodroma hositata. For many years this bird has been regarded as extinct, the last recorded capture having been made in 1871 , but recently reports have become current that odd examples have been seen. The present position is summed up in a short article in the Journal of the Society for the Preservation of the Fauna of the Empire (Sept. 1932, p. 17). In 1900 Richmond stated that he had seen three, more have been observed in Haiti, and on May 2, 1932, Mary Rose (of Roseau, Dominica) invited a naturalist to examine a strange bird found lying helpless at her door after a stormy night. The naturalists who saw it (it died on May 26) agree that it was a 'diablotin' ; and apparently the bird, although extremely rare, still breeds in the mountain fastnesses of Dominica. It is gratifying to find that steps were at once taken to ensure so far as possible the safety of the remnant, and on July 1 a special legislative order was issued granting the petrel full protection.

\section{Magnetic Declination in the United States}

THE U.S. Coast and Geodetic Survey makes magnetic observations at a set of repeat stations every five years, and publishes the results at similar intervals, in the form of tables of secular variation, and of charts showing the results of the original complete survey, made mainly between 1900 and 1910 , brought up to date. A recent pamphlet by D. L. Hazard ("Magnetic Declination in the United States, 1930", U.S. Dept. of Commerce, Coast and Geodetic Survey, Washington; Serial 540, 1932 ; pp. 40, 10 cents) does this for the magnetic declination; the chart gives isogonic lines at $1^{\circ}$ intervals, and lines of equal annual change at $I^{\prime}$ intervals. It contains much tabular matter and information of value to land surveyors, and is issued at a very low price.

\section{Meldola Medal}

THE Meldola medal (the gift of the Society of Maccabrans) is awarded annually to the chemist whose published chemical work shows the most promise and is brought to the notice of the adminis. trators during the year ending December 31 prior to the award. The recipient must be a British subject not more than thirty years of age at the time of the completion of the work. The medal may not be awarded more than once to the same person. In awarding the medal for 1932, the adjudicators will, unless exceptional circumstances arise, give special consideration to work in physical or inorganic chemistry. The next award will be made in January 1933. The Council of the Institute of Chemistry would therefore be glad to have its gttention directed, before December 31, to work of the character indicated. Communications should be addressed to the Registrar of the Institute, 30 Russell Square, London, W.C.I. 